\title{
Genetic parameters for milk coagulation properties in Estonian Holstein cows
}

\author{
M. Vallas, ${ }^{*}{ }^{1}$ H. Bovenhuis, $\neq$ T. Kaart, ${ }^{*} \dagger$ K. Pärna, $† \S$ H. Kiiman, ${ }^{*} \dagger$ and E. Pärna ${ }^{*} \dagger$ \\ *Institute of Veterinary Medicine and Animal Sciences, Estonian University of Life Sciences, Kreutzwaldi 1, 51014 Tartu, Estonia \\ †Bio-Competence Centre of Healthy Dairy Products, Kreutzwaldi 1, 51014 Tartu, Estonia \\ $\ddagger$ Animal Breeding and Genomics Centre, Wageningen University, PO Box 338, 6700 AH Wageningen, the Netherlands \\ §Institute of Mathematical Statistics, University of Tartu, J.Liivi 2, 50409 Tartu, Estonia
}

\begin{abstract}
The objective of this study was to estimate heritabilities and repeatabilities for milk coagulation traits [milk coagulation time (RCT) and curd firmness $\left(\mathrm{E}_{30}\right)$ ] and genetic and phenotypic correlations between milk yield and composition traits (milk fat percentage and protein percentage, urea, somatic cell count, $\mathrm{pH}$ ) in first-lactation Estonian Holstein dairy cattle. A total of 17,577 test-day records from 4,191 Estonian Holstein cows in 73 herds across the country were collected during routine milk recordings. Measurements of RCT and $\mathrm{E}_{30}$ determined with the Optigraph (Ysebaert, Frepillon, France) are based on an optical signal in the nearinfrared region. The cows had at least 3 measurements taken during the period from April 2005 to January 2009. Data were analyzed using a repeatability animal model. There was substantial variation in milk coagulation traits with a coefficient of variation of $27 \%$ for $\mathrm{E}_{30}$ and $9 \%$ for the log-transformed RCT. The percentage of variation explained by herd was $3 \%$ for $\mathrm{E}_{30}$ and $4 \%$ for RCT, suggesting that milk coagulation traits are not strongly affected by herd conditions (e.g., feeding). Heritability was 0.28 for RCT and 0.41 for $\mathrm{E}_{30}$, and repeatability estimates were 0.45 and 0.50 , respectively. Genetic correlation between both milk coagulation traits was negligible, suggesting that RCT and $\mathrm{E}_{30}$ have genetically different foundations. Milk coagulation time had a moderately high positive genetic (0.69) and phenotypic (0.61) correlation with milk $\mathrm{pH}$ indicating that a high $\mathrm{pH}$ is related to a less favorable RCT. Curd firmness had a moderate positive genetic (0.48) and phenotypic (0.45) correlation with the protein percentage. Therefore, a high protein percentage is associated with favorable curd firmness. All reported genetic parameters were statistically significantly different from zero. Additional univariate random regression analysis for milk coagulation traits yielded slightly higher average heritabilities of 0.38 and 0.47 for $\mathrm{RCT}$ and $\mathrm{E}_{30}$
\end{abstract}

Received May 30, 2009.

Accepted April 6, 2010.

${ }^{1}$ Corresponding author: mirjam.vallas@emu.ee compared with the heritabilities of the repeatability model.

Key words: milk coagulation, heritability, genetic correlation, Estonian Holstein dairy cattle

\section{INTRODUCTION}

Recent trends indicate that an increasing percentage of milk produced in European countries is used for manufacturing cheese (Eurostat, 2009). At present, in Italy more than $75 \%$ (De Marchi et al., 2008), in Scandinavian countries 33\% (Wedholm et al., 2006), and in Estonia 60\% (Statistics Estonia, 2009) of milk is being used for cheese production. Milk coagulation properties are important to the quality and yield of cheese (Leitner et al., 2006; Wedholm et al., 2006; De Marchi et al., 2009); therefore, these properties become more important if an increasing percentage of milk is used for cheese manufacturing. Milk coagulation properties are commonly defined by milk coagulation time and curd firmness. A short milk coagulation time and a firmer curd are favorable for cheese production. Shorter milk coagulation time may be beneficial to cheesemaking because it leaves more time for curd firming during the coagulation process. A firmer curd during clotting is positively correlated with cheese yield (Aleandri et al., 1989; Martin et al., 1997). Ikonen et al. (1999a) observed greater cheesemaking efficiency from milk with good coagulation properties.

Milk coagulation is a complex process and is not understood in detail, but studies have indicated that it is affected by numerous factors including casein composition (Okigbo et al., 1985a), SCC (Politis and Ng-Kwai-Hang, 1988), concentrations of total casein and calcium (Storry et al., 1983; Summer et al., 2002), pH (Najera et al., 2003), genetic polymorphism of milk proteins (Van den Berg et al., 1992; Mayer et al., 1997; Ikonen et al., 1999b), stage of lactation (Okigbo et al., 1985b; Ostersen et al., 1997), season (O'Brien et al., 1999), and breed (Auldist et al., 2002, 2004; De Marchi et al., 2008). Although it has been suggested that genetic factors affect milk coagulation, few studies have quantified the extent to which genetic factors play a 
role. Reported heritability estimates for milk coagulation traits range from 0.15 to 0.40 (Ikonen et al., 1999c, 2004; Tyrisevä et al., 2004; Cassandro et al., 2008). Furthermore, only a few studies have reported genetic relationships between milk coagulation traits and milk production and composition traits (Ikonen et al., 1999c, 2004; Cassandro et al., 2008). Knowledge of the genetic parameters of milk coagulation traits and their associations with milk production is important when considering ways to improve milk coagulation by means of genetic selection. Before including milk coagulation traits in the breeding goal, the economic value of these traits needs to be determined. There is a large amount of information about the application of biotechnology to cheese manufacturing but very little about the feasibility of enhancing cheese production efficiency by the genetic improvement of milk coagulation.

The aim of this study was to estimate the heritability and repeatability for milk coagulation traits and their genetic correlation with milk yield and composition, SCS, urea, and pH levels.

\section{MATERIALS AND METHODS}

\section{Data Collection}

First-lactation milk samples were collected during routine milk recording as part of a development project for the Bio-Competence Centre of Healthy Dairy Products in Estonia during the period from April 2005 to January 2009. The herds were milked 2 or 3 times a day. The individual milk samples collected from the cows were a mixture of all test-day milkings or only the morning, afternoon, or evening milkings on the testday. Milk samples were immediately preserved with Bronopol (Knoll Pharmaceuticals, Nottingham, UK) and stored at $4^{\circ} \mathrm{C}$ during the transportation and analyzing periods. Milk samples with a $\mathrm{pH}<6.5$, indicative of colostrum (Bhandari and Singh, 2002), and noncoagulated milk samples $(\mathrm{n}=52)$ were excluded from the analysis. Additionally, farms with fewer than 10 cows and cows with fewer than 3 test-day records were removed. The final data set used for analyses consisted of 17,577 test-day records from 4,191 Estonian Holstein cows located in 73 herds across the country and that were daughters of 274 sires. The number of daughters per sire ranged from 1 to 267 . Each cow has 3 to 6 measurements collected during the different stages (7 to 305 DIM) of the first lactation.

Information about the cows, herds, and pedigrees was obtained from the Estonian Animal Recording Centre (EARC) and the Animal Breeders' Association of Estonia, and entered into the database COAGEN of the Bio-Competence Centre of Healthy Dairy Products.

\section{Laboratory Analysis}

The test-day milk yield was recorded and individual milk samples were analyzed for fat percentage, protein percentage, and urea using the MilkoScan 4000 and MilkoScan FT6000, and for SCC using the Fossomatic 400 and Fossomatic 5000 cell counter (all equipment from Foss, Hillerød, Denmark) at the Milk Analysis Laboratory of EARC, using methods suggested by the International Committee for Animal Recording (2009). Values of SCC were log-transformed to SCS: SCS = $\log _{2}(\mathrm{SCC} / 100,000)+3$.

The $\mathrm{pH}$ and milk coagulation properties were determined at the Laboratory of Milk Quality of the Estonian University of Life Sciences (Tartu, Estonia) generally $3 \mathrm{~d}$ after sampling. The proportion of milk samples with a maximum age of $7 \mathrm{~d}$ was very small $(<1 \%)$. The $\mathrm{pH}$ level of the milk was determined using a $\mathrm{pH}$ meter (Seven Multi, Mettler Toledo GmbH, Greifensee, Switzerland) at a temperature of $20^{\circ} \mathrm{C}$ before analyzing the milk coagulation properties. The latter were milk coagulation time (RCT, min) and curd firmness $\left(\mathbf{E}_{\mathbf{3 0}}, \mathrm{mm}\right)$. Before assessment of the milk coagulation properties, milk samples were heated to the renneting temperature $\left(35^{\circ} \mathrm{C}\right)$. The rennet (Milase MRS 750 international milk clotting units/mL; CSK Food Enrichment B.V., Ede, the Netherlands) used in the analyses was diluted 1:100 ( $\mathrm{vol} / \mathrm{vol})$ with distilled water, and $0.2 \mathrm{~mL}$ of the solution was added to $10 \mathrm{~mL}$ of milk. The milk coagulation properties were determined using the Optigraph (Ysebaert, Frepillon, France), which was developed by Ysebaert Dairy Division in partnership with Institut National de la Recherche Agronomique, Laboratoire de Génie et Microbiologie des Procédés Alimentaires (Thiverval-Grignon, France), to define coagulation characteristics in the laboratory, especially to answer the needs of cheese makers (Ysebaert Dairy Division, 2009).

Measurements made with the Optigraph are not based on a rheological measures but on an optical signal in the near-infrared region. During a coagulation test, the light emitted through the milk gradually weakens because of changes in the micellar structure of casein. The Optigraph then calculates the coagulation parameters (coagulation time, curd firmness, and speed of aggregation) by means of particular feature points extracted from the optical information acquired in real time. Optigraph system parameters were set as follows: $\mathrm{R}$ slope $=1.784$ and $\mathrm{R}$ offset $=-2.303$. Milk coagulation time was recorded directly based on the maximum first derivative of the signal. To determine the firmness of the curd, the Optigraph signal 30 min after the addition of the rennet was converted into millimeters using a calibration equation (Kübarsepp et al., 2005). 
Table 1. Number of observations (n), means, and coefficients of variation (CV) for test-day milk coagulation, production, and composition traits

\begin{tabular}{|c|c|c|c|}
\hline Trait & $\mathrm{n}$ & Mean & CV $(\%)$ \\
\hline Curd firmness $\left(\mathrm{E}_{30}\right)(\mathrm{mm})$ & 17,577 & 27.0 & 27 \\
\hline Milk coagulation time $(\mathrm{RCT})^{1}(\mathrm{~min})$ & 17,577 & 2.3 & 9 \\
\hline Milk yield (kg) & 17,575 & 25.9 & 28 \\
\hline Fat $(\%)$ & 17,536 & 4.05 & 17 \\
\hline Protein (\%) & 17,567 & 3.38 & 9 \\
\hline $\mathrm{SCS}^{2}$ & 17,567 & 2.9 & 65 \\
\hline Urea (mg/L) & 17,223 & 26.8 & 31 \\
\hline $\mathrm{pH}$ & 17,577 & 6.6 & 1 \\
\hline
\end{tabular}

${ }^{1}$ Log-transformed.

${ }^{2} \mathrm{SCS}=\left[\log _{2}(\mathrm{SCC} / 100,000)+3\right]$.

\section{Statistical Analysis}

Statistical analysis was carried out in ASReml (Gilmour et al., 2002) using the following repeatability animal model:

$$
\begin{aligned}
Y_{i j k l m n} & =\mu+\beta_{1} D_{I M_{i}}+\beta_{2} D_{I M}^{2}+\beta_{3} a g e+y s_{j} \\
& + \text { cys }_{k}+\text { herd }_{l}+\text { animal }_{m}+p e_{n}+e_{i j k l m n},
\end{aligned}
$$

where $Y_{i j k l m n}=$ dependent variable (log-transformed $\mathrm{RCT}, \mathrm{E}_{30}$, milk yield, milk protein and fat percentages, SCS, urea, $\mathrm{pH}) ; \mu=$ overall mean; $D I M_{i}=i$ th day in milk, modeled with quadratic polynomial; age = linear regression on age at calving; $\beta_{1}, \beta_{2}$, and $\beta_{3}=$ regression coefficients; $y s_{j}=$ fixed effect of sampling year-season $(j$ $=1, \ldots, 16$ with 3 -mo classes from April 2005 to January 2009); cys $_{k}=$ fixed effect of calving year-season $(k$ $=1, \ldots, 15$ with 3 -mo classes from December 2004 to August 2008); herd $_{l}=$ random effect of herd $(l=1, \ldots$, 73), herd $_{i} \sim N\left(0, \mathbf{I} \sigma_{h}^{2}\right) ; \mathbf{I}=$ identity matrix; animal $_{m}=$ random effect of animal $(m=1, \ldots, 17,185)$, animal $_{m} \sim N\left(0, \mathbf{A} \sigma_{a}^{2}\right) ; \mathbf{A}=$ additive genetic relationship matrix; $p e_{n}=$ random permanent environmental term $(\mathrm{n}=1, \ldots, 4,191), p e_{n} \sim N\left(0, \mathbf{I} \sigma_{p e}^{2}\right)$; and $e_{i j k l m n}=$ residual random error term, $e_{i j k l m n} \sim N\left(0, \mathbf{I} \sigma_{e}^{2}\right)$. For normality assumption, log-transformation of RCT was used.

Three generations of ancestors were included in the analysis and 17,185 animals were included in the relationship matrix. Heritabilities were estimated with univariate models, and genetic correlations were derived from bivariate models.

Heritability $\left(h^{2}\right)$ was calculated as

$$
h^{2}=\frac{\sigma_{a}^{2}}{\sigma_{a}^{2}+\sigma_{p e}^{2}+\sigma_{e}^{2}},
$$

repeatability $(r)$ was calculated as

$$
r=\frac{\sigma_{a}^{2}+\sigma_{p e}^{2}}{\sigma_{a}^{2}+\sigma_{p e}^{2}+\sigma_{e}^{2}},
$$

and the proportion of variation due to herds $(h r d)$ was calculated as

$$
h r d=\frac{\sigma_{h}^{2}}{\sigma_{h}^{2}+\sigma_{a}^{2}+\sigma_{p e}^{2}+\sigma_{e}^{2}},
$$

where $\sigma_{a}^{2}=$ additive genetic variation; $\sigma_{p e}^{2}=$ permanent environmental variation; $\sigma_{e}^{2}=$ residual variation; and $\sigma_{h}^{2}$ $=$ herd variation.

\section{RESULTS AND DISCUSSION}

\section{Descriptive Statistics}

Table 1 shows descriptive statistics of the milk coagulation traits, and milk production and composition traits. There was substantial variation in milk coagulation traits as indicated by the coefficient of variation (CV) of $27 \%$ for $\mathrm{E}_{30}$ and $9 \%$ for the log-transformed RCT. Milk yield had a CV similar to that of $\mathrm{E}_{30}(28 \%)$, whereas the CV was higher for urea (31\%). There was little variation in $\mathrm{pH}(\mathrm{CV}=1 \%)$.

\section{Systematic Environmental Effects}

Table 2 shows the fraction of total phenotypic variance due to herd, reflecting the relative importance of differences between herds, probably mainly because of differences in feeding. Milk coagulation properties were not strongly influenced by differences between herds: the proportion of variation due to the herd was 0.04 for RCT and 0.03 for $\mathrm{E}_{30}$. The proportion of the variance explained by herd was also low for milk composition traits. For milk yield, a substantial percentage of the variation was due to the herd (25\%). Tyrisevä et al. (2004) reported slightly higher proportions of variation explained by herd for RCT (6\%) and $\mathrm{E}_{30}(9 \%)$. Ikonen et al. (2004) reported similar results as in the present study with a small fraction of the variation explained by herd $(5 \%)$ for RCT and $\mathrm{E}_{30}$. Herd effects for milk yield, fat percentage, and protein percentage in studies by Tyrisevä et al. (2004) and Ikonen et al. (2004) were higher (ranging from 15 to $48 \%$ ) than our estimates. Milk coagulation properties therefore seem to be affected to a smaller extent by the herd environment than are milk composition traits. This suggests that it is difficult to improve milk coagulation properties by herd management factors such as nutrition. 
The effect of DIM on milk coagulation properties is shown in Figure 1. Rennet coagulation time increased toward the end of lactation and stabilized after d 180 to less favorable values. Curd firmness showed a different pattern with less favorable values during the first part of lactation and more favorable (higher) values toward the end of the lactation.

Variation in the time between milk sampling and analysis may also have an effect on milk coagulation properties. Ikonen et al. (2004) reported a significant effect of the time between milk sampling and analysis on curd firmness. We were not able to adjust for this effect, because this information was not available for all samples. Based on the design of the current study, we may state that the time between milk sampling and analysis could have varied from 1 to $7 \mathrm{~d}$. This variation was, however, much smaller than in the study by Ikonen et al. (2004) $(0-27 \mathrm{~d})$ and therefore is expected to have less effect on milk coagulation properties.

\section{Heritabilities and Repeatabilities}

Heritabilities and repeatabilities of all traits studied were statistically significantly different from zero $(P<$ $0.05)$. Heritabilities of milk coagulation properties were 0.41 for curd firmness and 0.28 for milk coagulation time (Table 2). The heritability estimate for RCT was similar to that reported by Ikonen et al. (2004) but somewhat higher than other estimates $(0.21$ to 0.25$)$ reported for Finnish and Italian dairy cattle populations (Ikonen et al., 1999c; Tyrisevä et al., 2004; Cassandro et al., 2008). Heritability of $\mathrm{E}_{30}$ was consistent with the estimate (0.4) reported by Ikonen et al. (1999c) but higher than other estimates (0.15 to 0.22$)$ available in literature (Ikonen et al., 2004; Tyrisevä et al., 2004; Cassandro et al., 2008). These differences may be due to genetically different cattle populations. The differ-

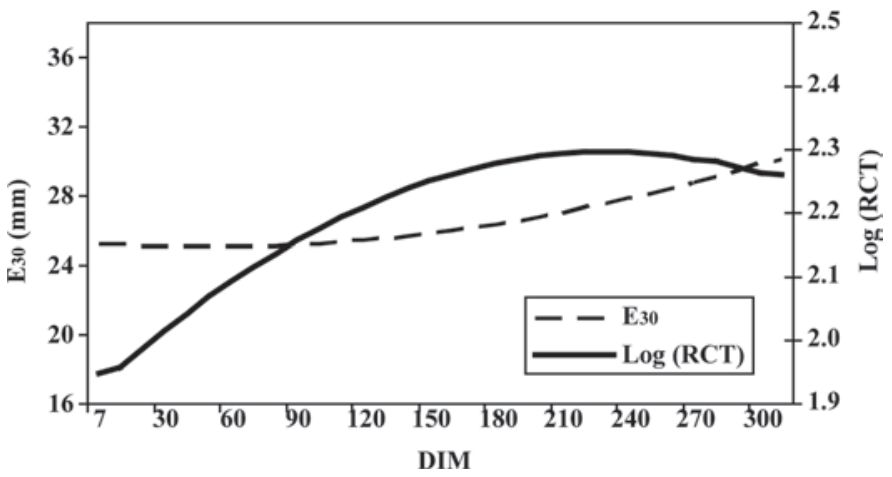

Figure 1. Lactation curve of log-transformed milk coagulation time $[\log (\mathrm{RCT})]$ and curd firmness $\left(\mathrm{E}_{30}\right)$ during the lactation period 7 to 305 DIM.

ence in methods might also have influenced variation in milk coagulation traits. Coefficients of variation for milk coagulation traits in the studies (Ikonen et al., 1999c) using the Formagraph (Foss) or in the studies (Ikonen et al., 2004; Tyrisevä et al., 2004; Cassandro et al., 2008) using Computerized Renneting Meter (Polo Trade, Monselice, Italy) are larger than in our study (ranging from 27 to $50 \%$ ). In our study, heritabilities for milk coagulation traits were higher than those for milk yield and composition traits. The highest heritability for a milk composition trait was for protein percentage (0.28); that for milk yield was 0.15 . Heritability was low for SCS (0.05) and urea (0.07).

Repeatabilities for RCT (0.45) and $\mathrm{E}_{30}(0.50)$ were high and of the same order of magnitude as repeatabilities for milk yield (0.47) and protein percentage (0.46). Urea had a low repeatability of 0.19 . The repeatability for SCS was moderately high (0.37).

Repeatabilities for RCT and $\mathrm{E}_{30}$ reported in Finnish studies by Ikonen et al. (1997) and Tyrisevä et al. (2003) are somewhat higher (from 0.57 to 0.68 ) than ours,

Table 2. The estimates of heritability $\left(\mathrm{h}^{2}\right)$, repeatability $(\mathrm{r})$, proportion of variance due to herd (hrd), and total phenotypic variance $\left(\sigma_{P}^{2}\right)^{1}$ for the traits studied

\begin{tabular}{lccrr}
\hline Trait & $\mathrm{h}^{2}(\mathrm{SE})$ & $\mathrm{r}(\mathrm{SE})$ & $\mathrm{hrd}(\mathrm{SE})$ & \multicolumn{1}{c}{$\sigma_{P}^{2}$} \\
\hline Curd firmness $\left(\mathrm{E}_{30}\right)(\mathrm{mm})$ & $0.41(0.04)$ & $0.50(0.01)$ & $0.03(0.01)$ & 49.27 \\
Milk coagulation time $(\mathrm{RCT})^{2}(\mathrm{~min})$ & $0.28(0.04)$ & $0.45(0.01)$ & $0.04(0.01)$ & 3.15 \\
Milk yield (kg) & $0.15(0.03)$ & $0.47(0.01)$ & $0.25(0.03)$ & 38.00 \\
Fat (\%) & $0.19(0.03)$ & $0.32(0.01)$ & $0.06(0.01)$ & 0.47 \\
Protein $(\%)$ & $0.28(0.04)$ & $0.46(0.01)$ & $0.06(0.01)$ & 0.06 \\
SCS $^{3}$ & $0.05(0.02)$ & $0.37(0.01)$ & $0.03(0.01)$ & 3.50 \\
Urea $(\mathrm{mg} / \mathrm{L})$ & $0.07(0.02)$ & $0.19(0.01)$ & $0.11(0.02)$ & 64.73 \\
pH & $0.24(0.03)$ & $0.36(0.01)$ & $0.06(0.01)$ & 0.31 \\
\hline
\end{tabular}

${ }^{1} \sigma_{P}^{2}=\sigma_{a}^{2}+\sigma_{p e}^{2}+\sigma_{e}^{2} \cdot \sigma_{\mathrm{a}}=$ additive genetic variance, $\sigma_{\mathrm{pe}}=$ permanent environmental variance, and $\sigma_{\mathrm{e}}=$ residual variance.

${ }^{2}$ Log-transformed.

${ }^{3} \mathrm{SCS}=\left[3+\log _{2}(\mathrm{SCC} / 100,000)\right]$. 
Table 3. Phenotypic (above the diagonal) and genetic correlations (below the diagonal; SE in parentheses) between milk coagulation properties, production, and composition traits ${ }^{1}$

\begin{tabular}{|c|c|c|c|c|c|c|c|c|}
\hline Item & $\begin{array}{c}\mathrm{E}_{30} \\
(\mathrm{~mm})\end{array}$ & $\mathrm{RCT}$ & $\begin{array}{l}\text { Milk yield } \\
\quad(\mathrm{kg})\end{array}$ & $\begin{array}{l}\text { Fat } \\
(\%)\end{array}$ & $\begin{array}{c}\text { Protein } \\
(\%)\end{array}$ & SCS & $\begin{array}{c}\text { Urea } \\
(\mathrm{mg} / \mathrm{L})\end{array}$ & $\mathrm{pH}$ \\
\hline Curd firmness $\left(\mathrm{E}_{30}\right)(\mathrm{mm})$ & & -0.22 & -0.06 & 0.11 & 0.45 & 0.01 & 0.02 & -0.15 \\
\hline Fat $(\%)$ & $0.25(0.09)$ & $-0.10(0.10)$ & $-0.65(0.09)$ & & 0.25 & 0.12 & -0.03 & -0.05 \\
\hline Protein (\%) & $0.48(0.07)$ & $0.19(0.10)$ & $-0.51(0.09)$ & $0.49(0.08)$ & & 0.16 & -0.11 & -0.02 \\
\hline $\mathrm{SCS}^{3}$ & $-0.04(0.15)$ & $-0.06(0.15)$ & $0.12(0.18)$ & $-0.05(0.16)$ & $-0.02(0.15)$ & & -0.17 & 0.12 \\
\hline
\end{tabular}

${ }^{1} \mathrm{SE}$ of phenotypic correlations were 0.01 to 0.02 .

${ }^{2} \log$-transformed.

${ }^{3} \mathrm{SCS}=\left[\log _{2}(\mathrm{SCC} / 100,000)+3\right]$.

which may also reflect the different measuring aspects of coagulation in these studies. The high repeatability estimates for RCT and $\mathrm{E}_{30}$ in our study, however, show that only a few measurements are needed for reliable genetic estimation of milk coagulation properties.

\section{Genetic and Phenotypic Correlations}

Genetic correlation between the 2 milk coagulation properties (Table 3) was negligible, suggesting that milk coagulation time and curd firmness measured by the Optigraph are mainly influenced by different genes. Other correlations reported here were significantly different from zero $(P<0.05)$. Phenotypic correlation between the 2 milk coagulation properties was slightly higher $(-0.22)$. Both estimates were lower than those reported in previous studies (Ikonen et al., 1999c, 2004; Tyrisevä et al., 2004; Cassandro et al., 2008), ranging from -0.89 to -0.96 . This result may indicate that the Optigraph device used in our study measures somewhat different aspects of milk coagulation compared with the devices used in previous studies (Formagraph and Computerized Renneting Meter), whose measurements of coagulation traits are based on direct measurement of viscosity. In our research, the Optigraph uses an optical signal, which is transformed to values for $\mathrm{E}_{30}(\mathrm{~mm})$ by using a calibration equation (Kübarsepp et al., 2005).

Genetic correlations between milk coagulation and milk yield and composition traits were mainly low. Curd firmness had the highest genetic correlation with milk protein percentage (0.48), suggesting that a high protein percentage results in a favorable $\mathrm{E}_{30}$. Cassandro et al. (2008) reported a correlation of 0.44 between $\mathrm{E}_{30}$ and protein percentage, which is in agreement with our results. The genetic correlations of -0.24 and -0.07 reported by Ikonen et al. (1999c, 2004) on the same traits, however, are different. These inconsistencies in- dicate that many factors may influence the relationship between $\mathrm{E}_{30}$ and protein percentage, such as sample size, breed, model and devices, and variation in time between milk sampling and analysis.

Milk coagulation time had the strongest genetic correlation with $\mathrm{pH}(0.69)$. A high $\mathrm{pH}$ level is therefore associated with a less favorable RCT. This result is consistent with previous studies (Ikonen et al., 1999c, 2004; Cassandro et al., 2008), which also reported a moderate to high genetic correlation between RCT and $\mathrm{pH}$ (0.40 to 0.81$)$. A moderate to high genetic correlation $(-0.30$ to -0.85$)$ between $\mathrm{E}_{30}$ and $\mathrm{pH}$ observed in previous studies (Ikonen et al., 1999c, 2004; Cassandro et al., 2008), however, was not found in our study; we estimated a zero genetic correlation between $\mathrm{E}_{30}$ and $\mathrm{pH}$.

Curd firmness showed a weak positive genetic correlation with milk fat percentage $(0.25)$ and a weak negative genetic correlation with milk yield $(-0.29)$. Therefore, selection for improved curd firmness may be associated with a somewhat higher fat percentage and slightly reduced milk production. Genetic correlations for $\mathrm{E}_{30}$ with milk yield and fat percentage were negligible in previous studies (Ikonen et al., 1999c, 2004; Cassandro et al., 2008).

Phenotypic correlations between milk coagulation properties and milk composition traits were similar or somewhat lower than the corresponding genetic correlations, except for slightly stronger phenotypic correlations between coagulation properties $(-0.22)$ and for $\mathrm{E}_{30}$ with $\mathrm{pH}(-0.15)$. Previous studies (Ikonen et al., 1999c, 2004; Cassandro et al., 2008) reported weak phenotypic correlations between milk coagulation traits and milk yield and composition traits, except for a moderately strong correlation between milk coagulation traits and $\mathrm{pH}$ and a moderate correlation for $\mathrm{E}_{30}$ with protein percentage. We found a somewhat higher 
positive phenotypic correlation for protein percentage with both milk coagulation properties and a lower phenotypic correlation between $\mathrm{E}_{30}$ and $\mathrm{pH}$ level.

The association of $\mathrm{E}_{30}$ with protein percentage can be explained by the key role of caseins in the milk coagulation process. Aggregation of casein micelles, the second phase of rennet coagulation process, starts only after about $87 \%$ of $\kappa$-casein is enzymatically degraded (Lucey, 2002). Van Hooydonk et al. (1986) reported that the optimum $\mathrm{pH}$ for hydrolysis of $\kappa$-casein is in the range from 5.1 to 5.3. This could explain the positive phenotypic correlation between RCT and $\mathrm{pH}$ levels, suggesting that a lower $\mathrm{pH}$ shortens RCT.

To our knowledge, no genetic and phenotypic correlations between milk coagulation traits and urea have been published. All genetic and phenotypic correlations of urea with other milk composition traits and milk yield were low and nonsignificant in our study. Our results were of the same magnitude as the values reported by Stoop et al. (2007), except for the high genetic correlation between urea and SCS (0.85) reported by Stoop et al. (2007).

The average SCS in our study was slightly lower than the values derived from the monthly reported average SCC (Estonian Animal Recording Centre, 2008) for cows in milk recording during 2008 (92\% of all cows in Estonia). For this reason, probably, we did not find any nonzero genetic correlations between SCS and milk coagulation traits. Ikonen et al. (2004) and Cassandro et al. (2008), however, reported that lower SCS are associated with improved milk coagulation properties. Some authors report that SCC has an unfavorable effect on milk coagulation properties at the phenotypic level (Politis and Ng-Kwai-Hang, 1988; O'Brien et al., 2001); Somers et al. (2002), however, did not find a significant effect of SCC on milk coagulation properties. To investigate a possible nonlinear relationship for SCS with RCT and $\mathrm{E}_{30}$, we performed additional analyses in which SCS was included as a linear and as a quadratic covariate in the model. The results showed a small unfavorable effect of higher SCS $(P<0.05)$ on RCT and $\mathrm{E}_{30}$. Adjusting for SCS differences in the model did not affect the estimated heritabilities.

In general, genetic and phenotypic correlations among milk yield and composition traits were in accordance with previous studies (Ikonen et al., 1999c, 2004; Cassandro et al., 2008).

\section{Genetic Parameters with a Random Regression Analysis}

In this article we used a repeatability model, which showed a good fit to the data (standard deviation of residuals was 1.17 for log-transformed RCT and 4.40 for
$\mathrm{E}_{30}$ ) and residual independence of DIM (residual and squared residual correlations across DIM were $<0.05$ for both milk coagulation traits). Because residuals were independent of lactation stage, variation due to DIM was sufficiently described by a repeatability model. For milk coagulation traits, however, additional univariate random regression models with second-order Legendre polynomials for the additive genetic and permanent environmental effects (except for first-order Legendre polynomial for permanent environmental effect of RCT) were applied to compare heritability and repeatability estimates and residuals with results from repeatability model analysis. Residual standard deviations of the random regression model were somewhat smaller than residuals from the repeatability model (standard deviation of residuals from repeatability and random regression model were 1.17 and 1.06, respectively, for $\mathrm{RCT}$ and 4.40 and 3.40, respectively, for $\mathrm{E}_{30}$ ). Based on monthly averages of residuals, differences between both models were small; however, the random regression model showed a somewhat better fit in the last 2 (mo 9 and 10) lactation months for curd firmness. Average heritability across lactation was 0.38 for RCT and 0.47 for $\mathrm{E}_{30}$. Heritability of RCT increased toward the end of lactation and had a maximum of 0.44 in lactation mo 6 and 7. The heritability for $\mathrm{E}_{30}$ showed an increase during lactation and a maximum of 0.51 in mo 8 to 10 of lactation. Average repeatability estimates were 0.53 for RCT and 0.58 for $\mathrm{E}_{30}$.

\section{CONCLUSIONS}

In our study of 17,577 test-day records from 4,191 first-lactation Estonian Holstein cows, we found RCT and $\mathrm{E}_{30}$ to be highly heritable. Genetic correlations of the milk coagulation traits with milk production and composition traits were weak; therefore, selection for milk coagulation properties is not expected to result in a strong deterioration of milk production and composition. Genetic and phenotypic correlations between milk coagulation time and curd firmness were different from those reported in previous studies, indicating that coagulation aspects measured by the new Optigraph device and other devices used may be different. Therefore, further research is needed to study the effect of the Optigraph milk coagulation measurements on cheese yield and quality.

\section{ACKNOWLEDGMENTS}

The research leading to these results was co-financed by the European Community's Regional Development Fund in the framework of the Competence Centre Programme of the Enterprise Estonia under project no. 
EU22868, carried out by the Bio-Competence Centre of Healthy Dairy Products, and by the Targeted Finance Project 1080045s07. The people from EARC (Tartu, Estonia), Animal Breeders' Association of Estonia (Keava), Institute of Veterinary Medicine and Animal Sciences of the Estonian University of Life Sciences (Tartu), especially Ivi Jõudu, are warmly thanked for their contribution in the collection and laboratory analysis of the data and the database COAGEN. Johan van Arendonk (Department of Animal Sciences, Wageningen University and Research Centre, the Netherlands) is warmly thanked for the opportunity of the research period at the Animal Breeding and Genomics Centre of Wageningen University. The Archimedes Foundation DoRa scholarship that enabled this visit is gratefully acknowledged.

\section{REFERENCES}

Aleandri, R., J. S. Schneider, and L. G. Buttazzoni. 1989. Evaluation of milk for cheese production based on milk characteristics and Formagraph measures. J. Dairy Sci. 72:1967-1989.

Auldist, M. J., K. A. Johnston, N. J. White, W. P. Fitzsimons, and M. J. Boland. 2004. A comparison of the composition, coagulation characteristics and cheese making capacity of milk from Friesian and Jersey dairy cows. J. Dairy Res. 71:51-57.

Auldist, M., C. Mullins, B. O'Brien, B. T. O'Kennedy, and T. Guinee. 2002. Effect of cow breed on milk coagulation properties. Milchwissenschaft 57:140-143.

Bhandari, V., and H. Singh. 2002. Physical Methods. Pages 93-101 in Encyclopedia of Dairy Sciences. Vol. 1. H. Roginski, J. W. Fuquay, and P. F. Fox, ed. Academic Press, San Diego, CA.

Cassandro, M., A. Comin, M. Ojala, R. Dal Zotto, M. De Marchi, L. Gallo, P. Carnier, and G. Bittante. 2008. Genetic parameters of milk coagulation properties and their relationships with milk yield and quality traits in Italian Holstein cows. J. Dairy Sci. 91:371-376.

De Marchi, M., G. Bittante, R. Dal Zotto, C. Dalvit, and M. Cassandro. 2008. Effect of Holstein-Friesian and Brown Swiss breeds on quality of milk and cheese. J. Dairy Sci. 91:4092-4102.

De Marchi, M., C. C. Fagan, C. P. O'Donnell, A. Cecchinato, R. Dal Zotto, M. Cassandro, M. Penasa, and G. Bittante. 2009. Prediction of coagulation properties, titratable acidity, and $\mathrm{pH}$ of bovine milk using mid-infrared spectroscopy. J. Dairy Sci. 92:423-432.

Estonian Animal Recording Centre. 2008. Results of animal recording in Estonia 2008. http://www.jkkeskus.ee/english/sisu/ aastaraamat_2008.pdf Accessed June 28, 2009.

Eurostat. 2009. Production of cheese. http://epp.eurostat.ec.europa. $\mathrm{eu} / \mathrm{tgm} /$ table.do? tab $=$ table\&init $=1 \&$ plugin $=1 \&$ language $=\mathrm{en} \& \mathrm{pc}$ ode=tag00040 Accessed May 25, 2009.

Gilmour, A. R., B. J. Gogel, B. R. Cullis, S. J. Welham, and R. Thompson. 2002. ASReml User Guide Release 2.0. VSN International, Hemel Hempstead, UK.

Ikonen, T., K. Ahlfors, R. Kempe, M. Ojala, and O. Ruottinen. 1999c. Genetic parameters for the milk coagulation properties and prevalence of non-coagulating milk in Finnish dairy cows. J. Dairy Sci. 82:205-214.

Ikonen, T., A. Morri, A.-M. Tyrisevä, O. Ruottinen, and M. Ojala. 2004. Genetic and phenotypic correlations between milk coagulation properties, milk production traits, somatic cell count, casein content and pH of milk. J. Dairy Sci. 87:458-467.

Ikonen, T., M. Ojala, and O. Ruottinen. 1999b. Associations between milk protein polymorphism and first lactation milk production traits in Finnish Ayrshire cows. J. Dairy Sci. 82:1026-1033.
Ikonen, T., M. Ojala, and E.-L. Syväoja. 1997. Effects of composite casein and beta-lactoglobulin genotypes on renneting properties and composition of bovine milk by assuming an animal model. Agric. Food Sci. Finl. 6:283-294.

Ikonen, T., O. Ruottinen, E.-L. Syväoja, K. Saarinen, E. Pahkala, and M. Ojala. 1999a. Effect of milk coagulation properties of herd bulk milks on yield and composition of Emmental cheese. Agric. Food Sci. Finl. 8:411-422.

International Committee for Animal Recording. 2009. International agreement of recording practices. Guidelines approved by the General Assembly held June 18, 2008. http://www. icar.org/Documents/Rules\%20and\%20regulations/Guidelines/ Guidelines_2009.pdf Accessed May 13, 2010.

Kübarsepp, I., M. Henno, O. Kärt, and T. Tupasela. 2005. A comparison of the methods for determination of the rennet coagulation properties of milk. Acta Agric. Scand. Anim. Sci. 55:145-148.

Leitner, G., O. Krifucks, U. Merin, Y. Lavi, and N. Silanikove. 2006. Interactions between bacteria type, proteolysis of casein and physico-chemical properties of bovine milk. Int. Dairy J. 16:648 654 .

Lucey, J. A. 2002. Rennet coagulation of milk. Pages 286-293 in Encyclopedia of Dairy Sciences. Vol. 1. H. Roginski, J. W. Fuquay, and P. F. Fox, ed. Academic Press, San Diego, CA.

Martin, B., J. F. Chamba, J. B. Coulon, and E. Perreard. 1997. Effect of milk chemical composition and clotting characteristics on chemical and sensory properties of Reblochon de Savoie cheese. J. Dairy Res. 64:157-162.

Mayer, H. K., M. Ortner, E. Tschager, and W. Ginzinger. 1997. Composite milk protein phenotypes in relation to composition and cheese making properties of milk. Int. Dairy J. 7:305-310.

Najera, A. I., M. de Renobales, and L. J. R. Barron. 2003. Effects of $\mathrm{pH}$, temperature, $\mathrm{CaCl}_{2}$ and enzyme concentrations on the rennetclotting properties of milk: A multifactorial study. Food Chem. $80: 345-352$.

O'Brien, B., W. J. Meaney, D. McDonagh, and A. Kelly. 2001. The effects of refrigerated storage on the quality of raw milk. Aust. J. Dairy Technol. 56:213-218.

O'Brien, B., R. Mehra, J. F. Connolly, and D. Harrington. 1999. Seasonal variation in the composition of Irish manufacturing and retail milks 1 . Chemical composition and renneting properties. Ir. J. Agric. Food Res. 38:53-64.

Okigbo, L. M., G. H. Richardson, R. J. Brown, and C. A. Ernstrom. 1985a. Casein composition of cow's milk of different chymosin coagulation properties. J. Dairy Sci. 68:1887-1892.

Okigbo, L. M., G. H. Richardson, R. J. Brown, and C. A. Ernstrom. 1985b. Variation in coagulation properties of milk from individual cows. J. Dairy Sci. 68:822-828.

Ostersen, S., J. Foldager, and J. E. Hermansen. 1997. Effects of stage of lactation, milk protein genotype and body condition at calving on protein composition and renneting properties of bovine milk. J. Dairy Res. 64:207-219.

Politis, I., and K. F. Ng-Kwai-Hang. 1988. Effects of somatic cell counts and milk composition on the coagulating properties of milk. J. Dairy Sci. $71: 1740-1745$

Somers, J. M., T. P. Guinee, and A. L. Kelly. 2002. The effect of plasmin activity and cold storage of cheese milk on the composition, ripening and functionality of mozzarella-type cheese. Aust. J. Dairy Technol. 55:5-11.

Statistics Estonia. 2009. Agriculture statistical database. http://pub. stat.ee/px-web.2001/I_Databas/Economy/01AGRICULTURE/01 AGRICULTURE.asp Accessed May 25, 2009.

Stoop, W. M., H. Bovenhuis, and J. A. M. van Arendonk. 2007. Genetic parameters for milk urea nitrogen in relation to milk production traits. J. Dairy Sci. 90:1981-1986.

Storry, J. E., A. S. Grandison, D. Millard, A. J. Owen, and G. D. Ford. 1983. Chemical composition and coagulating properties of renneted milks from different breeds and species of ruminant. J. Dairy Res. 50:215-229.

Summer, A., M. Malacarne, F. Martuzzi, and P. Mariani. 2002. Structural and functional characteristics of Modenese cow milk 
in Parmigiano-Reggiano cheese production. Ann. Fac. Med. Vet. Univ. Parma 22:163-174.

Tyrisevä, A.-M., T. Ikonen, and M. Ojala. 2003. Repeatability estimates for milk coagulation traits and non-coagulation of milk in Finnish Ayrshire cows. J. Dairy Res. 70:91-98.

Tyrisevä, A.-M., T. Vahlsten, O. Ruottinen, and M. Ojala. 2004 Non-coagulation of milk in Finnish Ayrshire and Holstein-Friesian cows and effect of herds on milk coagulation ability. J. Dairy Sci. 87:3958-3966.

Van den Berg, G., J. T. M. Escher, P. J. de Koning, and H. Bovenhuis. 1992. Genetic polymorphism of $\kappa$-casein and $\beta$-lactogobulin in relation to milk composition and processing properties. Neth. Milk Dairy J. 46:145-168.
Van Hooydonk, A. C. M., H. G. Hagedoorn, and I. J. Boerrigter. 1986. pH-induced physico-chemical changes of casein micelles in milk and their effect on renneting. 1. Effect of acidification on physicochemical properties. Neth. Milk Dairy J. 40:281-296.

Wedholm, A., L. B. Larsen, H. Lindmark-Månsson, A. H. Karlsson, and A. Andrén. 2006. Effect of protein composition on the cheesemaking properties of milk from individual dairy cows. J. Dairy Sci. 89:3296-3305.

Ysebaert Dairy Division. 2009. Optigraph. http://www.ysebaert.com/ ysebaert/optigraphuk.htm Accessed Dec. 10, 2009. 